\title{
Tana Panrita Kitta: Track Record of Panrita-Anreguru in Sinjai
}

\author{
Muh. Anis ${ }^{1}$, Muh. Judrah ${ }^{2 *}$, Amir Hamzah ${ }^{1}$ \\ ${ }^{1}$ Ushuluddin and Islamic Communication Islamic Counseling Guidance, Sinjai, Indonesia \\ ${ }^{2}$ Tarbiyah and Teacher Training Islamic Religious Education Master's Program Sinjai, Indonesia \\ *Corresponding author. Email: totangka077@gmail.com
}

\begin{abstract}
Sinjai was once known as Tana Panrita Kitta (the land of Islamic scholars). This means that Sinjai has a lot of expertise in literacy in Islamic science. The Muslim clergy were later known as panrita-anreguru. This study aims to discuss the meaning of panrita-anreguru and its characters throughout history. To this end, historical methodologies have been used, namely: heuristics, Critical Sources, Source Analysis, and Interpretation. It has been found that the beginning of XVII century Islam was accepted by the Sinjai people. Since then, Islamization has been dynamic and massive. This is due to the collaboration of scholars with the king / leader. In its development, it appears Panrita (Expert) or Anreguru (Professor). Panrita-Anreguru is a person who can transfer religious knowledge, role model, charismatic and dedicated. In the history string, names such as: Dato ri Bandang, Dato ri Tiro, Laming, Puang Belle, Puatta Massabangnge, To Maeppe daeng Situncu, Laming, Sheikh Ibrahim Rahmat, I Bolong daeng Makketti, Sheikh Abdul Rahman bin Abdullah Lamatti, Sheikh Abdul Jalil bin Abdullah Bulo-Bulo, Puang Kali Taherong, AGH Marzuki Hasan, AGH Djamaluddin Amien, AGH Abdullah Said, AGH Hamzah Ya'qub.
\end{abstract}

Keywords: Tana Panrita Kitta, panrita-anreguru

\section{INTRODUCTION}

In the past Sinjai was known as Tana Panrita Kitta (Islamic scientist Land). This means that Sinjai has a lot of expertise in Islamic science literacy. Or, Sinjai is a place of reproduction for Islamic scientist. Some people have slogan Tana Panrita Kitta for Sinjai area. It is a slogan that brings pride to the people of Sinjai. But what is the meaning of the panrita-anreguru and who they are? It is not widely known. The source of Islamic history in Sinjai is very limited. Although many scholarly tombs are scattered in various places and are believed to be the spread of scholarly knowledge, the results of this study are rather limited. There is not much literature on them that can be referred to in literature. Likewise, people's stories about them are still multiverse.

In 2002, Abu Hamid and his friends co-authored a book entitled "Traces of Sinjai's presence to Islam". This book talks a lot about the origin of the name "Sinjai", the kingdoms that once existed in Sinjai, and finally the history of Islam's entry into Sinjai. Some scholars have been mentioned but have not been discussed in detail[1]. Further, the thesis entitled "Islamization in Sinjai (An Historical Review) by Muh. Anis was published by Alauddin Graduate Program of the Islamic State University of Makassar in 2013. This thesis study is focused on the history of Islamic integration in Sinjai and the approach of propaganda [2]. In 2016, Sritimuryati wrote a book entitled "Islamization in Sinjai". The discussion in this book has written the names of Islamic spreaders in Sinjai [3]. In 2017, Abu Muslim published an article entitled "Taherong Puang; Biography and its Teachings". The discussion in this article focuses on
Taherong Puang Kali, a charismatic ulama and role model. The Taherong Puang Kali character is known by the Sinjai people as panrita-anreguru [4]. The four literatures have not yet fully explored the meaning and record of the trappings panrita-anreguru from the time of Islam's introduction to the present day.

With regard to these four studies, it should be considered to carry out a study focused on self-reporters in Sinjai. It starts with understanding the concept of an adventurer, and then chronologically records the trajectory of a worthy character called a surrogate. It is hoped that the findings of this article will supplement the literature on Islamic history and scholars in Sinjai. Hopefully, the discussion in this article can motivate and inspire scholarly biographical research and manuscript studies.

\section{METHODS}

This historical research seeks to examine figures who deserve to be regarded as scholars in Sinjai. Islamic cholars (ulama) who lived since the acceptance of Islam in the early period until the 20th century. Therefore, the steps taken by historical research are heuristics, source criticism, source analysis, and historiographic interpretation [5]. This research is a qualitative and descriptive analytical discussion description, which describes, explains, and explains historical facts [6]. Therefore, this study refers to written and oral sources. Written sources are lontara manuscripts, books, reports on previous research results, articles, and websites. While oral sources through interviews with several people who are considered competent and trusted [7]. The combination of written data sources with interviews, is an 
attempt to triangulate data validation, data analysis so that interpretation is born.

\section{RESULTS AND DISCUSSION}

\subsection{The Concept of The Tana Panrita Kitta and Panrita-Anreguru}

The sentence "Tana Panrita Kitta" consists of three words, namely: Tana, Panrita and Kitta. Etymologically, the word "Tana" has been popularly used and its meaning is commonly understood. In the Big Indonesian Dictionary, "Tana" means the planet where humans live, the third planet from the sun, the surface of the world; land [8]. From this it is known, the word "Tana" contains the meaning "world" human life and "land" - the place of human life. The meaning of the word "Tana" and "world", in Bugis summarized in the term "lino". The word "lino" in Bugis language contains three meanings, namely: world, earth, and silence. While the word "land" in the Bugis language is called "tana" [9].

The next, the word "panrita" in the Bugis-Dutch Language dictionary, "panrita" has two meanings, namely: scholars, scientists and architects [10]. Bugis expert, Cristian Pelras writes that the word "panrita" comes from the Sanskrit language: pandeta or ascetic. He explained that Panrita was a person who mastered the ins and outs of religion, was wise, pious, and honest [11]. Specifically, M. Said DM's idea means "Panrita" is a Big scholar or in Bugis language pronounced Panrita Loppo [9]. Explanation of C. Pelras and M. Said DM's idea explains that "Panrita" is a person who has a profound and insightful understanding of Islam which is accompanied by noble morals that deserve to be imitated. The semiotic association figure "panrita" can also be assumed to come from two words, namely panre: handyman, mapanre: berilmu and ita: see, mappaita: give instructions [9]. This linguistic understanding, bringing understanding to the figure of "panrita" is a person who has technical expertise and is able to transform his knowledge. In the context of the treasure of the terminology of the Bugis-Makassar society, Panrita is a scholar who has the expertise to transmit technically-practically the knowledge he masters.

Another perspective about "Panrita" was explained by Mochtar Pabottingi. He explained that the figure of Panrita is a person who testifies, sees and listens to a situation and states the real situation. As stated by this statement, Ilham Kadir wrote that when a Muslim scholar reached a level of expertise in the field of Islamic religious knowledge and was worthy of being a role model by his pious behavior, he was a Panrita [9].

Mochtar Pabottingi believes that the "panrita" figure is someone who is critical of the situation and is able to provide a description of reality. The "panrita" figure for Mochtar Pabottingi is not limited about Islamic scholars, but anyone who is able to make an intellectual contribution. Meanwhile, Ilham Kadir is more inclined to limit the figure of "panrita" limited to Islamic scholars [12].

There is a connotative term with "panrita" which is also known among the Bugis Makassar community, namely acca: smart, toacca: smart person. Referring to the existing literature, toacca is used for someone who deals in the fields of government, politics, diplomacy, and state / kingdom advisors, ethical conceptions of leadership and power. This is explicit in the phrase: obbiqi toaccae tassise-siseng mutanaiwi, nasaba maega tu patuju napau (occasionally call scholars to be asked for their opinions, because there are many virtues / truths in his speech) [13]. There is a Makassar language expression: lima pammajenganna butta lompoa (five factors of a country's collapse), one of them is the teanamo tomangngisangan ri lalang paqrasangnga (if there are no more domestic scholars) [14].

Wahyuddin Halim suggested the implicit opinion of Andi Zainal Abidin that panrita/topanrita were not only limited to appointing scholars, but also included scholars and technocrats in a government area. In the lontara manuscript recording, Wahyuddin Halim released several names of toacca or topanrita figures. The names include: To Ciung Maccae in Luwu (Ages XV), Neneq Maggading in Suppa (Century XV), La Tiringeng To Taba and La Taddampare ri Maggalatung in Wajo (XV Century), La waniaga arung bila in Soppeng (Century XVI), Neneq Pasiru (XV century) and La Pagala Neneq Mallomo (Century XVI) in Sidenreng, La Mellong Kajao Laliddong in Bone (Century XVI), Karaeng Botolempangang (XVII Century) and I Mangadacinna Daeng Sitaba Karaeng Pattingngaloang (XVII Century) in Gowa-Tallo [15].

The overall acceptance and spread of Islam in South Sulawesi gave a new term, namely anreguru (Bugis language) or anronguru (Makassar language). This term is a predicate for a great scholar typical of the Bugis Makassar. As a form of respect for them, it is usually told by anregurutta (our great teacher). Ilham Kadir quoted Ahmad's opinion that anreguru is someone who has knowledge in a high Islamic religion and has ampe-ampe madeceng (good behavior / morality. Anregurutta's call is the highest legitimacy of one's religious hierarchy [16].

Panrita is an individual who has qualified expertise. Technically they are able to transform their expertise to others. In fact, more than it they are role models, asking questions and asking for advice. The expertise-scientific contribution to the community is assessed as a need. Therefore, the panrita gets legitimacy as a person who must be respected. If intellectuals contravene the politicalleadership realm, then he is believed to be a toacca in panrita. If he contributes to Islamic scholarship, then he is respected as an anreguru in panrita.

Now, mahfum is understood and accepted that Panrita is also Anreguru. His expertise is undeniable, his skills are very practical, and his vision is reality. It is no exaggeration if the figure of the panrita is matched with the guardian. As guardian, the panrita not only mastered the knowledge of Shari'a but they were kasyaf. This kasyaf ability was obtained from God for their mujahalah for al-Islam. The manifestation of God's grace to them is known as karamah. For his sincere dedication to fostering the people, Firdaus Muhammad wrote AGH (Anregurutta Hajji; Guru Hajji) in front of their names [17]. The title "Hajji (male), Hajjah (female)" in the realm of thinking of Bugis and Makassarese people, is a symbol of "perfection" of one's Islam.

Finally, the term of kitta: kitab. Specific M. Said DM's idea explains that the word "kitta" refers to a book that contains knowledge in Islam. He wrote a sentence, maegani kitta 
nabaca; many books have been read. Makkitta; reading the book, iaro panritae macca senna mabbaca kitta; the scholars are very good at reading books [9]. By laymen, kitta / books / thick books that read bald letters without punctuation. For people who are mass-minded (studying at Islamic boarding schools) known as Kitab Kuning (yellow book).

To have the ability to read kitta, then you must first master the science of nahwu and sharaf science. In addition, someone who wants to "conquer" the yellow book must memorize the mufradat [18]. On this basis, a person's ability to read kitta makes it mapanre: knowledge. More than it, if someone is able to explain and teach it so that other people are able to master it too, then this is where he gets the title panrita kitta. Because that person has technically practically transmitted scientific skills in the form of text, the meaning of text and context.

\subsection{Tracks of Panrita-Anreguru Records in Sinjai}

Sniffing out the track record of the existence and activities of Panrita in Sinjai begin at the beginning of the acceptance of Islam. Concentration Dato ri Tiro preached in the Tiro area, was significantly strategic for the Sinjai community. The location of the area between Sinjai and Tiro is relatively close, it should be suspected that there are some Tosinjai (Sinjai people) who study Islam there. Tosinjai who had studied with Dato ri Tiro, returned to their respective hometowns to spread Islam.

Puang Belleq or Lagalago, one of the students of Dato ri Tiro actively preaching in Sinjai. His tomb is located in Tana Tekkoe, Bakaqe Hamlet, East Sinjai District. In the past, this tomb area was under the control of the Kingdom of Tondong. He studied Islam directly to Dato ri Tiro [19]. In 1606, King Tondong named Kahare Daeng Mallabasa sent Puang Belle and Petta Massambangnge from the Kingdom of Bulo-bulo to meet Abdul Jawad Khatib Bungsu di Tiro. After a while, La Pated was sent back to Petta Massambangnge to invite and pick up Abdul Jawad Khatib Bungsu to the Tellu Limpoe area [1]. A contemporary and a soldier from Puang Belle, a figure named Topalekke was also found. He was quite active in preaching in Bulo-Bulo, Tondong, and Lamatti. His speech got a hard challenge from the Bissu (Ancient Bugis Priests), so they conflict. After his death, his da'wah efforts were continued by his son Mallakade [3]. Regarding the arrival and missionary activist Dato ri Tiro in Sinjai, no exact information has yet been obtained.

On the top of the Paliqe-Tondong hill there is a tomb which according to the elders in this village are ulama (scholar). His name is not yet known, the people know him Puang Salama. He is contemporary with Puang Belle and Puatta Massabangnge [20]. In a text written by Taba Daeng Panolo, the figure of Puatta Massabangnge, Puang Belle, Tuanta Yusufu actively preached in the Tondong area to Sinjai Central and West [21]. The last name of Tuanta Yusufu, is supposed to be the real name of Puang Salama. This figure is identical to the name Syek Yusuf Al Makassary-Tuanta Salama, but it is believed to be different.

Apart from To Maeppe Daeng Situncu there is not much information about Anrongguru-Panrita in the West Sinjai area. The burial complex in the village of Bonto Salama is a silent witness to the Islamization activities in this area, strictly speaking it requires in-depth research [2]. There is a great opportunity to explore who To Maeppe Daeng Situncu is. The area of speech activities in the Turungang Kingdom area became the starting point of the argument. And, the Kingdom of Turungang is quite well known in its time as the oldest entity in Pitu Limpoe [22].

The correlation with the description above has not fully described the technical process of the spread of Islam in Sinjai. Figures such as Puang Belle, Puatta Massabangnge, and Puang Salama are only known as disseminators of Islam. Technically, how do they teach Islam? There is no convincing information yet. Do they teach Islam by lecturing around the village? Or are they domiciled somewhere doing recitation? Did the recitation they did use certain books? Included in this case is the writing they left behind. However, in fact they are Anreguru-Panrita who are respected by the Sinjai community.

The initial indicator of the activity of the Panrita's activities in Sinjai, can be traced when Dato ri Bandang lives in the Kingdom of Bulo-Bulo. With the support of La Pateddungi, he coached 40 local people (local people). At the same time, he demonstrated practically the implementation of several Islamic Shari'a, including: slaughtering animals, marrying, taking care of bodies, Eid al-Fitr, Eid al-Adha, Qurban, and managing zakat. For the effectiveness and effectiveness of his formation to 40 mokki, he pioneered the establishment of mosques in Wattang. Not less than 20 days the mosque was established as a result of community cooperation [23]. The existence of 40 mokki which was fostered by Dato ri Bandang shows the efforts of regeneration regeneration. Also, showing the vision of Dato ri Bandang continuity of Islamization in the future. Dato ri Bandang lived in the Kingdom of Bulo-Bulo for approximately 3 years, namely from 1607 to 1610 [24].

In the kingdom of Lamatti, Laming - a merchant and Anreguru-Panrita married Arab women. He is believed to be guardian by the local community, because it is remembered as the Guardian of the Pute (wali pute). It is not related to his tomb. The story, after the Isha prayer is in the mosquito net then mallajang (disappears). The most prominent recitation material besides Sufism is the Pillars of Faith and Pillars of Islam[1]. He also remembered the title of the Hajji Pute, because his daily life always wore white robes and white horses. Has 30 horses as trading vehicles to Bantaeng[25]. Apart from being recognized as Anreguru-Panrita, he was nicknamed Hajji Loppo because of the conglomerate's prestige. He was a rice merchant all the way to Bantaeng, home with coffee at Lamatti. His marriage gave birth to a child named Bora (Ibrahim). From this Bora descent then gave to Panrita-Panrita in Lamatti-Sinjai [26]. His existence in Lamatti was contemporary with La Tenri Ruwa-Raja Bone XI, around 1611 [1], [27].

From the XVII-XVIII century, several names of characters were believed to be instrumental in Islamization in Sinjai. In Bulo-Bulo and Tondong, there is Laloasa Daeng Parani, Raja Daeng Mattojeng, Ismaila Daeng Pahonging intensely teaches Islam [28]. In Manimpahoi, there is I Bolong Daeng Makketti [1]. Puang Salama (1670) taught Islam in Patalassang and its surroundings, Puang Jawa, Puang Janggo, Said Abu Bakar, Puang Topekkong, Said Husain 
[3]. In Bonto Pale Hamlet near Mangarabombang, there is the Tomb of Sheikh Ibrahim Rahmat / Pang Tuang / Puassengngo [29]. The da'wah mujahid were of average nobility.

Reaffirming the activity and continuity of Panrita's history in Sinjai, between 1607-1610 a mosque was established in Bulo-Bulo [23]. In 1613 a mosque was built in Mangarabombang, in Manimpahoi 1617, Nur Mosque in Balangnipa in 1660 [1]. There is a claim that the $\mathrm{Al}$ Mujahidin mosque in Aruhu district the oldest Bulupoddo in Sinjai. This mosque was founded by I Towa Suro Raja Lamatti which was Islamized by Dato ri Tiro. However, there is no information about when this mosque was built. Around the nineteenth century the mosque was once restored by Makkuraga Daeng Pagau who was also King Lamatti. It is commonly known, the mosque is not only a place of prostration and remembrance, but a maktab and a center for fostering Muslims.

Thomas Gibson's research shows the phenomenon of the to sinjaie (the Sinjai people). Around 1637 to 1644 a network of tareqat Sattariyah and Qadiriyah was formed which involved the sinjai people. He released based on the BiraBulukumba genealogy script the names of Panrita came from Sinjai. In the text included, among others: Al Shaykh Abdul Rahman bin Abdullah Lamatti (panre keke: Little Clever), Syek Abdul Jalil bin Abdullah Bulo-Bulo (toayya teacher: oldest teacher), Sheikh Abdul Basir bin Abdul Jalil al Bira wa al Bugisi (to ri masigiqna: who is in his mosque), he built a mosque in Bira. Sheikh Abdul Rahman bin Abdullah Lamatti was also known in Selayar with Puang Janggo[30]. After being traced, Sheikh Abdul Basir bin Abdul Jalil al Bira wa al Bugisi is believed to also come from Sinjai [22]. Based on the description above, over the first four decades of the seventeenth century, the emergence of a very progressive committee. The Panrita, not only become Anreguru in their own area, but also in other regions. There are some Anreguru-Panrita names that are difficult to know, they are only remembered as Pang Tuang or Puang Salama. The assumptions that can be put forward are related to this, namely: they are immigrants not native Sinjai people or peranakans born in Sinjai. It may be, this pattern of expression of respect and respect for their dedication. Just to note, the descendants and / or Arabians (Tuang) and Indian / Pakistani (Tambi) have merged into the Sinjai community. Entering the end of the seventeenth century until the eighteenth century, almost there is no information and data on the progress of the command in Sinjai. This is due to the political constellation in the peninsula of South Sulawesi again heating up. The confrontation of the Tallo Gowa Kingdom with the Kingdom of Bone caused open war. The involvement of each of the allies of the two kingdoms, especially the VOC-Dutch partisanship in Bone, increasingly made matters worse. This has resulted in a lack of information about the regeneration of Anreguru-Panrita. This is because literaryists are more interested in writing political events and wars.

In connection with this situation, the history of the existence of the tareqat Khalwatiyah community is important. In Sinjai, the concentration of these tareqat followers is in East Lenggo-Lenggo Sinjai and in Pattongko-Tafillasa Middle Sinjai. This tareqat community was intentionally backed because it was directly related to Syek Yusuf Al Makassary
Abul Mahasin Hadyatullah Tajul Khalwaty. The influence of his panhandle at the end of the seventeenth century was not only as narrow as South Sulawesi-Sinjai but extended to Banten [31]. The approach of Sufism (Tareqat Khalwatiyah) gained a place in society besides Sattariyah and Qadiriyah [32]. The last two tareqats are mentioned, there are no communities that openly practice their teachings. The Naqshabandiyah tareqat now exists even though it only showed itself around the 1990s.

In the nineteenth century the existence of Anreguru-Panrita again could be detected. Puang Imang Lamuru's tomb in the courtyard of the Rayatul Hidayah Lompu mosque, revealed a little search. At Puang Akkung's house facing the mosque, dozens of books are still stored and cared for. These books are relics of Puang Imang Lamuru [33]. Regarding the ministry, his tomb is one of the favorite pilgrimage figures of the other Panrita, namely Puang Kali Taherong [34]. Is the fragment of the title "Lamuru" related to the district of Kec. Lamuru in Kab. Bone? The question is important, because Lamuru is quite well known by historians and archaeologists.

Puang Kali Taherong or KH. Muhammad Thahir (18841977), renounced his nobility, quit as a prosecutor in Bantaeng (1951-1958), then embraced religion and actively preached [35]. He left a paper entitled Singkerru Limappuloe [36]. H. Ali admitted that the book had been stored, "one day someone borrowed it but until now it has not been returned, I have also forgotten who that person is", he admitted. The habit that becomes a routine for Puang Kali is to visit the Lempangeng cemetery every Friday night after the Isha prayer. And, occasionally visit the Puang Imang Lamuru tomb in Lompu-Sinjai Rayatul Hidayah Mosque complex [34]. This Singkerru Limappuloe paper is in the form of microfilm at the Office of the Regional Archives and Library of South Sulawesi Province, Makassar.

At Nur Balangnipa Mosque (standing 1660) Puang Kali Taherong focused its missionary activities [37]. Puang Kali Taherong divides its two study groups. First, general recitation for all worshipers. Second, special recitation for certain people, located on the second floor of the Nur Mosque. Muh. Amin, the special recitation was once attended by KH. Marzuki Hasan, KH. Lanre Said, and KH. Abd. Muin [38]. These three people became known as Anreguru-Panrita. At the house of the grandson of Puang Kali Taherong there were a number of books - one wooden cupboard. These books are read and taught to their students [39].

In the twentieth century, traces of panrita easier founded. In the twentieth century, literacy related to historical themes and biographies of characters has increased. In AnreguruttaLiterasi book Sulselbar Ulama by Firdaus Muhammad released 50 scholars. He included three scholars from Sinjai, namely Anreguruttta Haji (AGH) Marzuki Hasan (19172006), AGH Djamaluddin Amien (1930-2014), and AGH Abdullah Said (1945-1998) [17]. This book should be an inspiration to conduct in-depth research with the content "AG / AGH" specifically in the Sinjai area.

AGH Marzuki Hasan did not only establish Darul Istiqamah Islamic boarding schools in Maros and Sinjai, but he also actively wrote. At least 16 works have been written, including: Pribadi Muslim, Ikhtisar Fiqih Sunnah, Man Hual Mujahid, Tafsir Al-Quranil Karim (Bahasa Arab), Miftahud 
Dakwah (bahasa Arab, ikhtisar dari kitab Miftahul Khithabah), Tuntunan Pelaksanaan Shalat, Akhlakul Kharimah, Kedudukan Wanita dalam Islam (Bahasa Bugis), Pakaian Wanita Dalam Pandangan Islam (Bahasa Bugis), Dasar-Dasar Dinul Islam, Sejarah Islam (Bahasa Arab), Tuntunan Khotbah (Bahasa Bugis), Ulumul Qur'an, Kitab Syiam (Bahasa Bugis), Shalat Malam Sumber Kekuatan Jiwa: Tafsir Tematik QS. Al Muzammil [40].

Reading AGH's writings, Marzuki Hasan, explained the figure who concentrated in Tarbiyah Islamiyah. The field of science of other religions controlled by AGH Marsuki Hasan is the field of Fiqh (Shari'a Law). His skills in the field of Fiqh caused him to be appointed as Minister of Information in the DI / TII movement (1950-1965) in South Sulawesi led by Kahar Muzakkar. Joining and becoming an official in DI / TII shows AGH figure Marzuki Hasan is qualified in the Islamic syahasah.

AGH Djamaluddin Amien is a figure of multitalented cleric. He is known as an educator, organizer, academic, da'i, and politician. He was the Chairperson of the South Sulawesi Muhammadiyah Regional Leadership for three periods [17]. Apart from Sinjai and Makassar, he is also widely known by the Bantaeng community as scholars. His dedication to the Muhammadiyah missionary movement caused him to be more popular as a Muhammadiyah scholar. It is not an exaggeration to say that AGH Djamaluddin Amin focused his wisdom on the charges through the organization.

AGH Abdullah Said is a charismatic scholar from Sinjai SulSel. He is still one trah with AGH Marzuki Hasan. His uncle named AGH Hasan Syuaib is qadi in Bulo-Bulo, better known as Puang Kali Cambang. AGH Abdullah Said is the founder of the Hidayatullah Islamic boarding school in Balikpapan. His preaching was expressed through literacy in Suara Hidayatullah magazine, from 1986 to 1993 [17]. Until now, the Suara Hidayatullah magazine in the printed edition still exists, can also be accessed online: m.hidayatullah.com. In the village of Panreng, his relatives called him Puang Ngesseng (Muhsin Kahar). A brief quote about AGH Abdullah Said, representing an expansive panrita figure.

AGH Hamzah Ya'qub or Haji Kube teaches books in Darul Hikmah Lenggo-lenggo boarding school. The founder of the founder of the University of Syekh Yusuf in Tangeran Prov. Banten. Besides Mappangaji Tudang: Teaching the Book, writing is also productive. The recitation was attended by the general public and several leaders of Islamic boarding schools in Sinjai. No less than 14 papers in printed books can be found. In the 1980s, he took care of the Fajr Study at the ANtv Station [41]. The writings include: Etos Kerja IslamiPetunjuk Pekerjaan yang Halal dan Haram dalam Syariat Islam, Filsafat Agama-Titik Temu Akal dan Wahyu, Etika Islam-Pembinaan Akhlakul Kharimah-Suatu Pengantar, Pemurnian Aqidah dan Syari'ah Islam, Kode Etik Dagang Menurut Islam-Pola Pembinaan Hidup dan Berekonomi, Ilmu Ma'rifat, Publisistik Islam-Teknik Dakwah dan Leadership, Industrilisasi Dalam Pandangan Islam, Integrasi Tauhid dan Teknologi, Tinjauan Ekonomi Maritim Dalam Al Qur'an, Tingkat Ketenangan dan Kebahagiaan Mu'min, Filsafat Ketuhanan, Leadership Islam [42]. It can be emphasized that AGH Hamzah Ya'qub is a diaspora panrita figure from Sinjai.

Furthermore, Halide, former Chancellor of the University of Fajar Makassar, was the recipient of the award from the
Investor Magazine, Jakarta, because he was concerned with developing Islamic economics in Indonesia. In 2010, he obtained a similar award from the Sharia Economic Community (MES) representative of Eastern Indonesia regional academics [43]. Halide's track record of concern for sharia economic developments was seen in 1996 in Mecca and 1980 in Islamabad-Pakistan. At that time, along with other figures such as Bakir Hasan, and Ismail Suni, Halide attended an international meeting on Islamic economics. In addition to being familiar as a sharia economist, the man who was born on September 29, 1936 is famous for being a prominent missionary in South Sulawesi. So no wonder his lectures were often heard in the Grand Mosque of Makassar, Radio RRI Nusantara IV since 1979 [44]. At the 53rd Anniversary, the 60th Bachelor and Postgraduate Graduation of UNISMUH Makassar on August 27, 2016, was entrusted to deliver scientific speeches entitled "Integrity, Professionals \& Entrepreneurship to Realize Progressing Islam".

The last figure in this paper is Abu Hamid (1934-2011). Humanist, anthropologist from Hasanuddin University, and former Rector of University 45 Makassar, died on Monday night, May 23, 2011 in Makassar [45]. The man born in Sinjai, March 3, 1934, devoted his life to the world of education. Not only that, he revitalized the history and philosophy of life of the Bugis-Makassar people through his books. The three books that get attention are Shaykh Yusuf; A Ulama, Sufi and Fighters, Passompe: Bugis Odyssey, and Siri and Pesse: The Self-Esteem of the Bugis Makassar, Mandar, Toraja [46]. Although it is not popularly known as Anreguru, he is panrita about the Muslim community in South Sulawesi. There are still many figures suspected of being included in the Anregurutta-Panrita category. These figures include: AGH Muhammad Nur Khalwatiyah Caliph in East Lenggo-Lenggo Sinjai, AGH Hasan Syuaeb aka Puang Kali Cambang qadi in Bulo-Bulo, Puang Cella Ulu, and Puang Mabbida.

\section{CONCLUSION}

Early XVII century Islam was accepted by the Sinjai community. Since then, Islamization has been dynamic and massive. This is due to the collaboration of scholars with the king / leader. The intensity and continuity of this collaboration eventually popularized the term Panrita (Member) or Anreguru (Professor). Panrita-anreguru is a person who can transfer religious knowledge, role model, charismatic and dedicated. Panrita-anreguru is an individual scholar who transforms his scientific expertise into someone else's. In fact, they are a role model, a place for questions and advice. Therefore, registrants have legitimacy as a person to be respected and respected.

In the XVII century the recorded registers include: Dato ri Bandang, Dato ri Tiro, Laming, Puang Belle, Puatta Massabangnge, To Maeppe Daeng Situncu, Laming, Shaykh Abdul Rahman bin Abdullah Lamatti, and Shaykh Abdul Jalil bin Abdullah Bulo-Bulo, Shaykh Ibrahim Rahmat. In the XVIII century, the continuation of the panrita-anreguru had no valid information found. In The XIX century, the panrita-anreguru figure reappears. It was started by Puang Kali Taherong, followed by AGH Marzuki Hasan, AGH 
[14] A. Z. Abidin, Capita Selekta Sejarah Sulawesi Selatan, I. Makassar: Hasanuddi University Press, 1999.

[15] W. Halim, "Arung, Topanrita dan Anregurutta Dalam Masyarakat Bugis Abad XX,” Al Ulum, vol. 12, no. Pemikiran Islam, p. 322, 2012.

We are grateful this study was supported by the Institute of Research and Community Services (LP2M) of the Islamic Institute of Muhammadiyah Sinjai.

\section{REFERENCES}

[1] A. Hamid, Jejak Kehadiran Sinjai Hingga Masuknya Islam, I. Makassar: Padat Jaya, 2002.

[2] M. Anis, "Islamisasi di Sinjai (Suatu Tinjauan Sejarah)," UIN Alauddin Makassar, 2013.

[3] Sritimuryati, Islamisasi di Sinjai, I. Makassar: Pustaka Sawerigading, 2016.

[4] A. Muslim, "Puang Kali Taherong; Biografi dan Karamahnya," Al Qalam, vol. 23, no. Keagamaan, 2017.

[5] S. Kartodirjo, Pendekatan Ilmu Sosial Dalam Metodologi Ilmu Sejarah, I. Jakarta: Gramedia, 1992.

[6] H. Kaelan, Metode Penelitian Agama, Kualitatif Indisipliner, I. Yogyakarta: Paramadina, 2010.

[7] I. Hasan, Pokok-Pokok Materi Penelitian Dan Aplikasinya, I. Bogor: Galia Indonesia, 2002.

[8] E. Setiawan, “Tanah,” Badan Pengembangan dan Pembinaan Bahasa, Kemdikbud (Pusat Bahasa), 2018.

[Online]. Available: https://kbbi.web.id/tanah.

[9] M. Ide Said DM, Kamus Bahasa Bugis-Indonesia, I. Jakarta: Depdikbud RI, 1977.

[10] B. Matthes, Boeegineesch-Hollandsch Woordenboak, I. Amsterdam: 'S Gravenhage, 1877.

[11] C. Pelras, The Bugis-Manusia Bugis, I. Jakarta: Nalar dan Forum Jakarta Paris, EFEO, 2006.

[12] I. Kadir, "Genealogi Ulama Bugis," https://makassar.tribunnews.com. [Online]. Available: https://makassar.tribunnews.com/2017/01/27/genealogiulama-bugis.

[13] A. Z. Abidin, Persepsi Orang Bugis Makassar Tentang Hukum Negara dan Dunia Luar, I. Bandung: Alumni, 1983.
[16] I. Kadir, "Gurutta, Anreguru, Panrita," Koran SINDO, 2012. [Online]. Available: https://www.academia.edu/37618597/Gurutta_Anregur u_Panrita.

[17] F. Muhammad, Anregurutta Literasi Ulama Sulselbar, I. Makassar: Nala Cipta Litera, 2017.

[18] A. Wahyudi, "Langkah-langkah Untuk Bisa Membaca Kitab Arab Gundul," https://muslim.or.id, 2013. [Online]. Available: https://muslim.or.id/ 13164langkah-langkah-untuk-bisa-membaca-kitab-arabgundul.html.

[19] Arif, "Puang Belleq," 2013.

[20] Hamid, "Puang Salama di Palie," 2017.

[21] D. Panolo, “Lontara Puatta Massabangnge," Sinjai, 1973.

[22] Muhannis, "Ulama Penyebar Islam di Sinjai," 2017.

[23] B. Gising, Attoriolongnge ri Tondong, Bulo-Bulo, Lamatti (Sejarah Kerajaan Bulo-Bulo, Tondong, Lamatti: Suatu Bentuk Manifestasi "Sinjai Bersatu." Makassar: Era Media, 2002.

[24] M. Anis, "Penerimaan Islam Di Sinjai Abad XVII (Analisis Perubahan Sosial Politik dan Budaya)," Makassar, 2018.

[25] Juaefa, "Laming, Wali Pute, Hajji Loppo,” 2017.

[26] Arida, "Wali Pute ri Lamatti," 2017.

[27] A. Daeng Patunru, Sejarah Bone, I. Ujung Pandang: Yayasan Kebudayaan Sulawesi Selatan, 1989.

[28] Muhannis, Karampuang dan Bunga Rampai Sinjai, I. Yogyakarta: Ombak, 2013.

[29] M. Ansar, "Syek Ibrahim Rahmat di Boto Pale," 2017.

[30] T. Gibson, Islamic Narrative and Authority in Souttheas Asia from the 16th to the 21st Century diterjemahkan oleh Nurhady Sieimorok dengan judul "Narasi Islam dan Otoritas di Asia Tenggara: dari Abad ke-16 hingga Abad ke-21, I. Makassar: Ininnawa, 2013. 
[41] Ismail, "Sosok AGH Hamzah Ya'qub,” 2019. dan XVII, I. Yogyakarta: Kurnia Kalam Sejahtera, 1995.

[32] A. Hamid, Syekh Yusuf Makassar-Seorang Ulama, Sufi, dan Pejuang, I. Jakarta: Yayasan Obor Indonesia, 1994.

[33] M. Haldum, "Asal Usul Puang Imang Lamuru," 2017.

[34] H. Ali, "Prilaku dan Karamah Puang Kali Taherong," 2015.

[35] A. A. A. Thahir, "Puang Kali Taherong alias KH. Muh. Thahir," 2015.

[36] Y. Ahmad, "Karya Tulis Puang Kali Taherong," 2015.

[37] S. Yahya, "Kepanritaan Puang Kali Taherong," 2015.

[38] M. Amin, "Sistem Pengajian Puang Kali Taherong," 2015.

[39] N. Umar, “Akhlak Puang Kali Taherong,” 2015.

[40] S. Yanuardi, KH. M. Arif Marzuki: Segulung Cerita Dari Maccopa, I. Solo: Tinta Medina, 2017.
[42] Http://unis.ac.id/, "Karya Tulis Hamzah Ya'qub," Buku-Buku Karangan Hamzah Ya'qub, 2019.

[43] S. Mappong, "Pengamat: Pemanfaatan Potensi ZIS Tekan Kesenjangan Sosial," https://kalsel. antaranews.com/berita/49808, 2017. [Online].

Available:

https://kalsel.antaranews.com/berita/49808/pengamatpemanfaatan-potensi-zis-tekan-kesenjangan-sosial.

[44] Khintan, "Prof Halide, Pakar Ekonomi Syariah dari Kampus Merah," https://identitasunhas.com, 2019. [Online]. Available: https://identitasunhas.com/profhalide-pakar-ekonomi-syariah-dari-kampus-merah/.

[45] Asnawin, "Prof Abu Hamid, Antropologi, dan Politik," http://pedomanrakyat.blogspot, 2011. [Online]. Available: http://pedomanrakyat.blogspot. com/2011/10/prof-abu-hamid-antropologi-danpolitik.html.

[46] N. A. Aziz, "Perginya Sang Kitab Hidup BugisMakassar," https://regional.kompas.com, 2011. [Online]. Available: https://regional.kompas.com/ $\mathrm{read} / 2011 / 05 / 24 / 19001983 /$ Perginya.Sang.Kitab.Hidup. BugisMakassar. 